\title{
G-QUADRUPLEX LIGANDS AS STABILIZER TARGETING TELOMERASE ENZYME AS ANTI CANCER AGENTS
}

\author{
HEMALATHA CN, VIJEY AANANDHI M* \\ Department of Pharmaceutical Chemistry and Analysis, School of Pharmaceutical Sciences, Vels University, Chennai, Tamil Nadu, India. \\ Email: hodpchemistry@velsuniv.ac.in
}

Received: 09 May 2017, Revised and Accepted: 25 May 2017

\section{ABSTRACT}

The human telomere stabilization with G-Quadruplex DNA tends to induce apoptosis. The molecular target of telomere cascade with a rigid molecular may show efficacious to treat cancer. The study of intercalation to human telomeric DNA with proposed ligand can be evaluated by the help of biophysical studies and biological studies. G-Quadruplex is one of the key epigenetic episodes of eukaryotes and prokaryotes, generally found in the telomeric end region, immunoglobulin switch recombination and the lagging strand of the DNA. These chemotherapeutic advances are not enough to maintain a life expectancy of cancer affected patients. A number of G-Quadruplex ligands such as acridine, perylene, and anthraquinones have been synthesized reported and evaluated them for the inhibitor activity. Therefore, translational research can pave the novel prospect to treat cancer in a fundamental way. In that connection, basic research showed G-Quadruplex phenomenon of DNA, which is having a great impact in this chemotherapy.

Keywords: Perylene derivatives, G-Quadruplex, Telomerase, Anticancer.

(C) 2017 The Authors. Published by Innovare Academic Sciences PvtLtd. This is an open access article under the CC BY license (http://creativecommons. org/licenses/by/4. 0/) DOI: http://dx.doi.org/10.22159/ajpcr.2017.v10i8.19797

\section{INTRODUCTION}

Guanine-rich nucleic acid sequences are capable of forming fourstranded structures termed G-Quadruplexes. It exists in Telomeres, Gene Promoters' and other important regions of eukaryote genome [1]. These structures have been studied using nuclear magnetic resonance, $\mathrm{X}$-ray diffraction and spectroscopic techniques $[2,3]$ and materialized as a significant biological target for telomerase inhibitors. Telomerase is a ribonucleoprotein enzyme binds to the telomeres which increase their length, and extends the lifespan of cells. A development of potential telomerase inhibitors carried out by the researchers using small molecules which are able to interact with telomeric DNAs and to induce uncommon DNA secondary structures, sequestered to telomerase [4]. A number of compounds have been studied such as porphyrins, disubstituted anthraquinones, trisubstituted acridine, dibenzo phenanthroline derivatives, and perylene derivatives [5]. Other telomerase inhibitors such as telomestatin, RHPS4, BRACO-19 stabilizes to form the G-Quadruplex (GGTTAG) structure, hence decreasing the efficiency of telomerase [6,7]. Several therapeutics targeting telomerase, such as Imetelstat (GRN163L) and Tertomotide (GV1001), are currently in Phase I, II, and III clinical trials to treat a wide range of cancers from solid tumors to non-small cell lung cancer, leukemia, lymphoma, and myeloma [8].

\section{ANTHRAQUINONE DERIVATIVES}

A non-nucleoside small molecule (Compound 1) was the first reported compound published by Sun et al. [9] and which inhibits (inhibitory concentration $50 \%\left[\mathrm{IC}_{50}\right] 23 \mu \mathrm{M}$ ) the telomerase enzyme by interaction with G-Quadruplex. Based on the study more number of isomeric forms of anthraquinones derivatives are screened synthesized and examined them for telomerase inhibitory activity. From the study, primary or tertiary amino groups, the position of the side chains is important for telomerase inhibition. Small library compounds of disubstituted anthraquinone amino acid derivatives, e.g., Compounds 2 and 3 show optimal telomerase inhibition $\left(\mathrm{IC}_{50} 0.8-1.5 \mu \mathrm{M}\right.$ ) with the residues Lys or Arg as side chains [10]. Guanidine derivative (Compound 4) also showed potent $\left(\mathrm{IC}_{50} 1 \mu \mathrm{M}\right)$ inhibitor activity for telomerase enzyme [11].

\section{ACRIDINE DERIVATIVES}

3,6 disubstituted acridine derivatives have been proposed by Harrison et al. [12] and this study states as the planar aromatic chromophore ring which stabilize, binds to G-Quadruplex and inhibits telomerase. The protonated heterocyclic nitrogen atom (Compound 5) at physiological $\mathrm{pH}$ interacts G-quadruplex by increasing electron deficiency $\left(\mathrm{IC}_{50} 1.35 \mu \mathrm{M}\right)$ [13]. In the acridine chromophore aniline substituent at $9^{\text {th }}$ position shows significant inhibitor activity for the Compound 6 (BRAC019) $\left(\mathrm{IC}_{50} 0.095 \mu \mathrm{M}\right)$ and Compound $7\left(\mathrm{IC}_{50} 0.060 \mu \mathrm{M}\right)$ [14]. The pentacyclic quinoa iridium salt RHPS4 (Compound 8) $\left(\mathrm{IC}_{50} 0.25 \mu \mathrm{M}\right.$ ) shows good pharmaceutical properties and efficiently transported into tumor cells [15]. Other acridine compounds such as polycyclic acridines (Compound 9) $\left(\mathrm{IC}_{50} 0.37 \mu \mathrm{M}\right)$ [16], quaternized quinoa [4, $3,2-\mathrm{kl}$ ] acridinium salts (Compound 10 ) ( $\left.\mathrm{IC}_{50} 0.38 \mu \mathrm{M}\right)$ [17], and 3, 6, 9- trisubstituted acridine derivatives (Compound 11$)\left(\mathrm{IC}_{50} 0.018 \mu \mathrm{M}\right.$ ) have been reported [18] and showed best telomerase inhibitor activity.

\section{PERYLENE DERIVATIVES}

Fedoroff et al. [19] reported the first potent telomerase inhibitor and iterated G-Quadruplex-bindingstudies by the Compound 12 (PIPER-N,N'bis [2-(1-piperidino)-ethyl]-3, 4, 9, 10-perylenetetracarboxylicdiimide) with very low $\mathrm{IC}_{50}$ range. A series of PIPER derivatives (e.g., Compound 13 [DAPER] and 14 [PIPER3]) has been synthesized which was found to inhibit telomerase with the $\mathrm{IC}_{50}$ values in the range of $10-20 \mu \mathrm{M}[20]$. The electrostatic interaction between the ligands plays a major role in telomerase inhibition. Rossetti et al. [21] reported a set of PIPER derivatives (e.g., Compound 15 [PIPER6] and Compound 16 [PIPER7]) which was showing to be more efficient than PIPER with the IC $_{50}$ values between 5 and $10 \mu \mathrm{M}$. These compounds with different side chains lead to inhibitor activity. Franceschin et al. [22,23] reported the distance of positive charges in the side chains and synthesized set of perylene derivatives (e.g., Compound 17 [DAPER 3C], Compound 18 [DAPER3C-Br], Compound 19 [DAPER4C 1, 6], and Compound 20 [DAPER 4C 1,7]) and evaluated for telomerase activity and shows $\mathrm{IC}_{50}$ value at about $5 \mu \mathrm{M}$. Further, he synthesized polyamide perylene diimides derivatives (e.g., Compound 21 [POL-3] and Compound 22 [POL-5]), which shows inhibition value between $\mathrm{IC}_{50} 7$ and $10 \mu \mathrm{M}$. 


\section{PORPHYRINE DERIVATIVES}

Wheelhouse et al. [24] reported cationic porphyrins, and among them, they found one of the Compound 23 (TMPyP4- [5, 10-15, 20-tetra(-N-Methyl-4-pyridyl)] porphine) as it stabilizes and stacked with G-Quadruplex DNA and inhibits telomerase enzyme with an $\mathrm{IC}_{50}$ value of $6.5 \pm 1.4 \mu \mathrm{M}$. Analogs of TMPyP4 (e.g., Compound $24-\mathrm{IC}_{50} 5 \mu \mathrm{M}$ ) have been reported and found as the positively charged substituent's on meso positions, and the size of substitution are important, and the face of porphyrins should be available for stacking [25].

\section{BISINDOLE DERIVATIVES}

A series of bisindole derivatives has been synthesized by Sasaki et al. [26] found as the phosphodiester group and a long alkyl chain would be the most important factors for the telomerase inhibition. Among the compounds, Compounds 25 and 26 were observed potent inhibitors with an $\mathrm{IC}_{50}$ value of $3.4 \mu \mathrm{M}$ and $2.5 \mu \mathrm{M}$, respectively. The hydrophobic group in indole derivative was also considered as an important factor for the inhibition.

\section{BERBERINE DERIVATIVES}

9 and 13 substituted berberine derivatives have been reported by Ma et al. [27] and Franceschin et al. [28], and among the compounds, Compounds 27 and 28 were observed to be the potent telomerase inhibitor by stabilizing G-quadruplex DNA with an $\mathrm{IC}_{50}$ value of $14 \mu \mathrm{M}$.

\section{MACROCYCLIC COMPOUNDS}

Telomestatin - Compound 29 was the most potent in vitro telomerase inhibitor, and it consists of one thiazoline and seven oxazole rings which will interact with G-Quadruplex with an $\mathrm{IC}_{50}$ value of $5 \mathrm{nM}[29,30]$. Barbieri et al. and Tera et al. [31,32] synthesized synthetic macrocyclic telomerase derivatives (e.g., Compound 30 \{Macrocyclic Hexazole [HXDV] $\}$ and Compound 31 [bistrioxazole acetate]) and found that the compound shows strong selectivity toward Quadruplex over duplex or triplex DNA with an $\mathrm{IC}_{50}$ value of $2 \mu \mathrm{M}$.

\section{TRIAZINE DERIVATIVES}

Riou et al. [33] reported series of triazine compounds and among the derivatives, bisquinoline substituted triazine Compound $32\left(\mathrm{IC}_{50} 0.041 \mu \mathrm{M}\right)$ observed potent telomerase inhibitor at nanomolar concentration.

\section{CONCLUSION}

In this review, we summarized the existing studies on the biological activities of telomerase inhibitors [34]. Numerous compounds have been identified and screened for telomerase inhibitor activity to develop and improve efficacious drugs with less toxicity. In silico drug design can play a significant role in all stages of drug development from the preclinical discovery stage to late stage clinical development [35]. Among the targets, telomerase was the enzyme which shows high concentration in carcinogen cells when compared to normal cells. From the various literature, we found out as the compounds acridines, perylene, anthraquinones, macrocyclic compounds, and porphyrins having a unique feature which interrupts the biochemical role present in the telomerase enzyme which stabilizes the G-Quadruplex DNA and arresting the growth of cancerous cells without affecting the normal cells, thus inducing apoptosis. These telomerase inhibitors may have a major role with the current anticancer agents in treating cancerous cells (Table 1).

\section{ACKNOWLEDGMENT}

The authors are thankful to Vels University (VISTAS) and its management for providing research facilities and encouragement. The author is obliged to DBT - Government of India (BT/Biocare/03/10047/2013-14) for providing financial assistance to carry out the research work. The authors are also thankful to the VLife Science Technologies (Amit Bedi) Pvt. Ltd, Pune, India, for providing the software for the QSAR study.

Table 1: List of G-Quadruplex stabilizing ligands

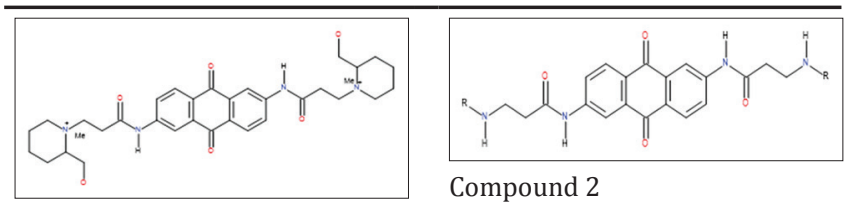

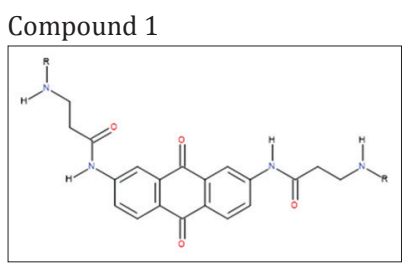

Compound 3

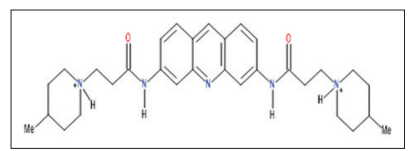

Compound 5

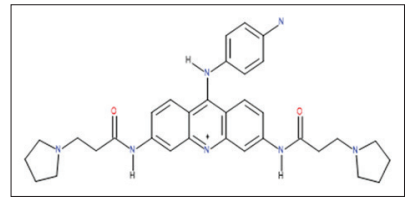

Compound 7

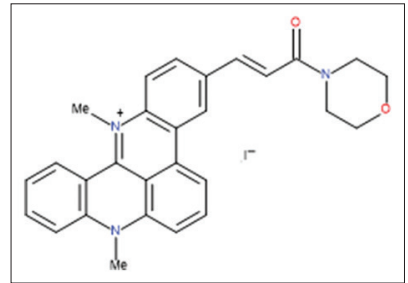

Compound 9

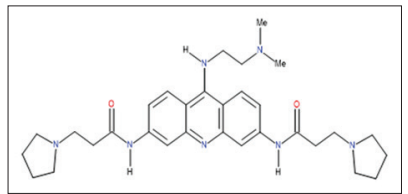

Compound 11

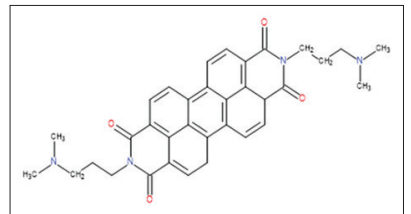

Compound 13

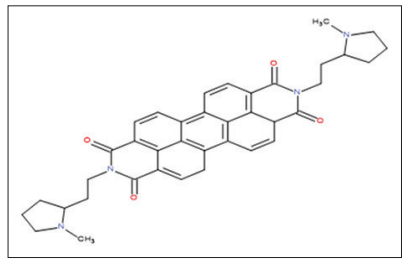

Compound 15

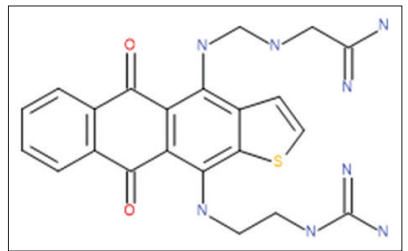

Compound 4

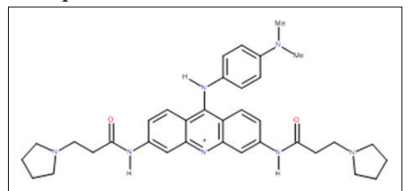

Compound 6

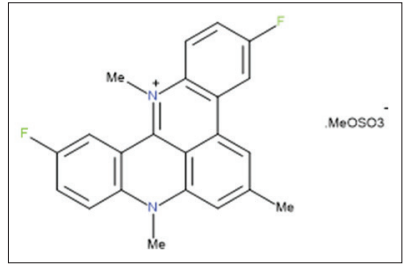

Compound 8

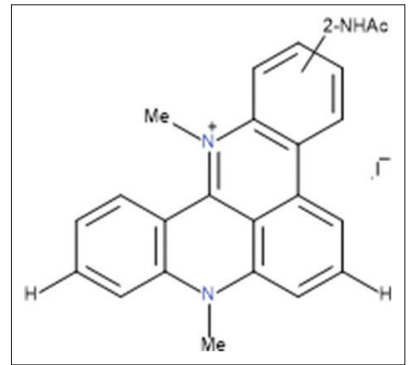

Compound 10

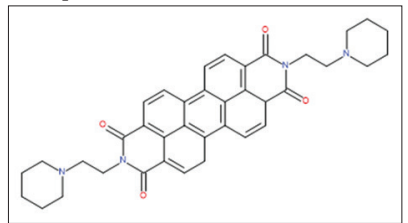

Compound 12

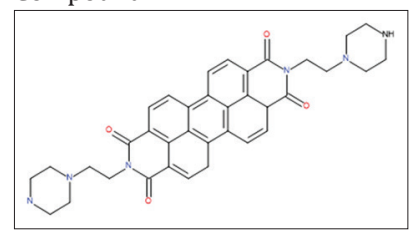

Compound 14

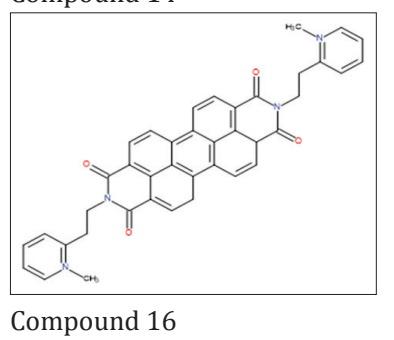


(Table 1: Continued...)

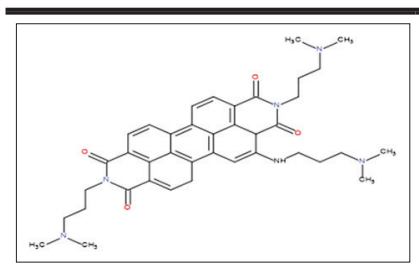

Compound 17

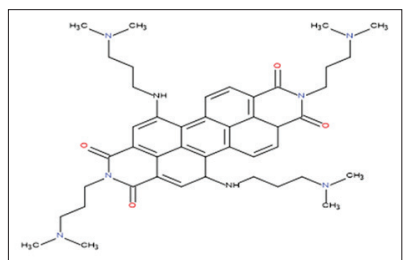

Compound 19

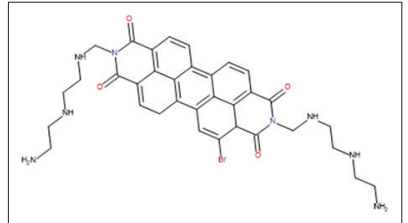

Compound 21

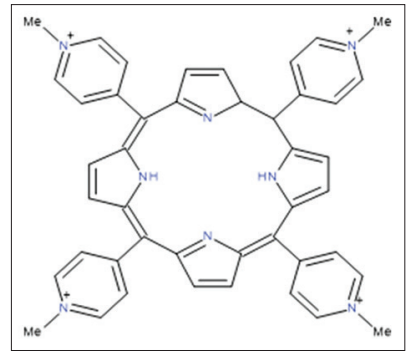

Compound 23

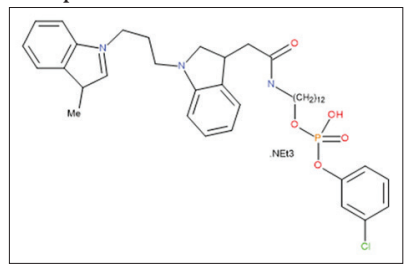

Compound 25

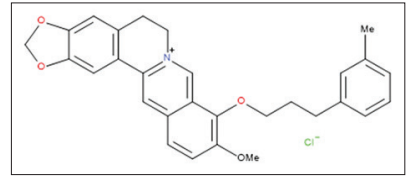

Compound 27

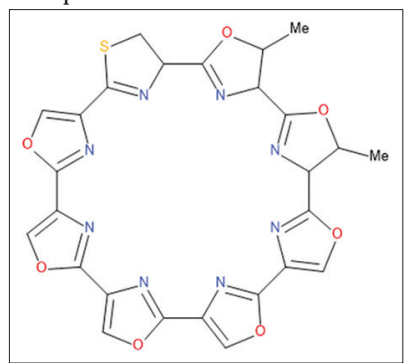

Compound 29

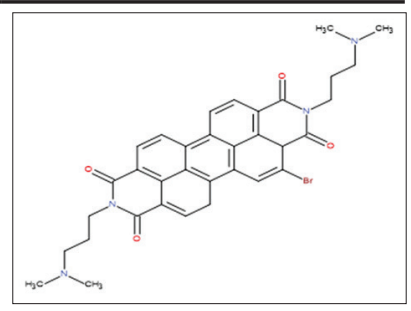

Compound 18

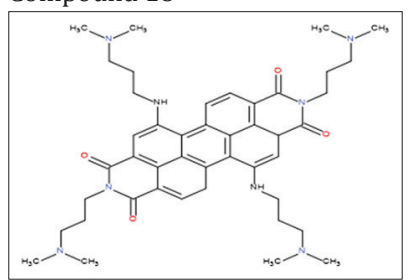

Compound 20

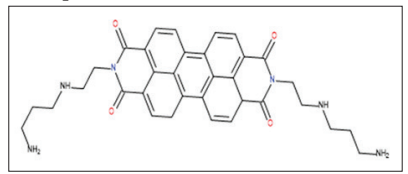

Compound 22

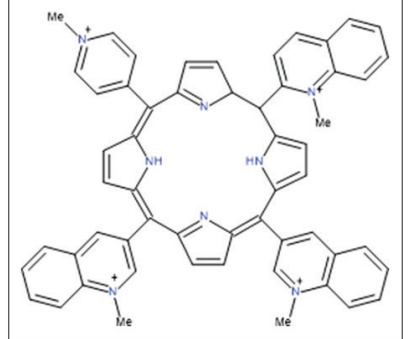

Compound 24

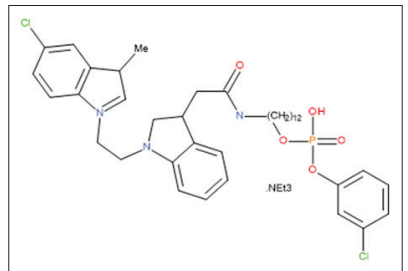

Compound 26

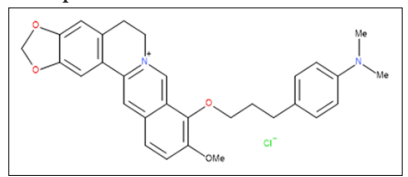

Compound 28

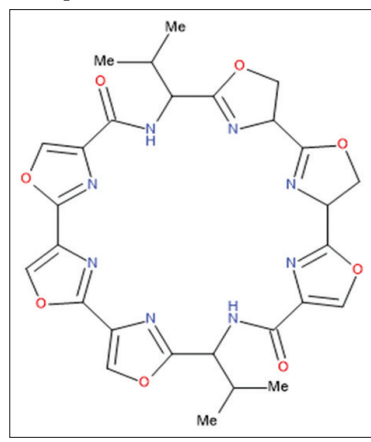

Compound 30
(Table 1: Continued...)

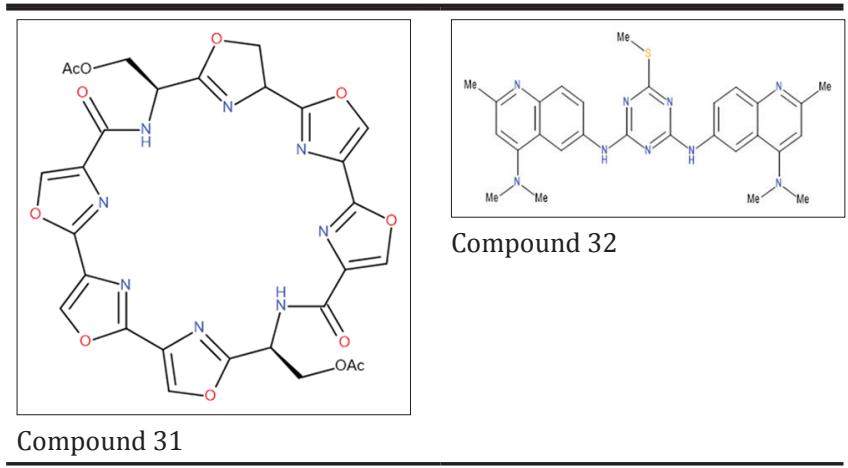

\section{REFERENCES}

1. Chu B, Yuan G, Zhou J, Ou Y, Zhu P. A new telomerase inhibitor and apoptosis-inducing agent in leukemia: Perylene derivative as G-quadruplex ligand Tel03. Drug Dev Res 2008;69:235-41.

2. Miyoshi D, Nakao A, Toda T, Sugimoto N. Effect of divalent cations on the anti-parallel G-Quartet structure of d-(G4T4G4). FEBS Lett 2001;25:3341-6

3. Keniry MA. Quadruplex structures in nucleic acids. Biopolymers 20002001;56:123-46.

4. Mergny JL, Helene C. G-quadruplex DNA: A target for drug design. Nat Med 1998;4:1366.

5. Rossetti L, Franceschin M, Bianco A, Ortaggi G, Savino M. Perylene diimides with different side chains are selective in inducing different G-quadruplex DNA structures and in inhibiting telomerase. Bioorg Med Chem Lett 2002;12(18):2527-33.

6. Harley CB. Telomerase and cancer therapeutics. Nat Rev Cancer 2008;8:167-79.

7. $\mathrm{Xu}$ Y. Chemistry in human telomere biology: Structure, function and targeting of telomere DNA/RNA. Chem Soc Rev 2011;40(5):2719-40.

8. Puri N, Girard J. Novel therapeutics targeting telomerase and telomeres. J Cancer 013;5:10.

9. Sun D, Thompson B, Cathers BE, Salazar M, Kerwin SM, Trent JO, et al. Inhibition of human telomerase by a G-quadruplex-interactive compound. J Med Chem 1997;40:2113-6.

10. Sissi GZ, Lucatello L, Pivetta C, Cadamuro SA, Fox KR, Neidle S, et al. Aminoacyl-anthraquinone conjugates as telomerase inhibitors: Synthesis, biophysical and biological evaluation. J Med Chem 2008;51:5566-74.

11. Shchekotikhin AE, Glazunov VA, Dezhenkova LG, Luzhkov YN, Sinkevich YB, Kovalenko LV, et al. Synthesis and cytotoxic properties of 4,11-bis[(aminoethyl)amino] anthra[2,3b]thiophene-5,10-diones, novel analogs of antitumor anthracene-9,10diones. Bioorg Med Chem 2009; 17:1861-9.

12. Harrison RJ, Gowan SM, Kelland LR, Neidle S. Human telomerase inhibition by substituted acridine derivatives. Bioorg Med Chem Lett 1999;9:2463-8.

13. Read MA, Wood AA, Harrison RJ, Gowan SM, Kelland LR, Dosanjh HS, et al. Molecular modeling studies on G-quadruplex complexes of telomerase inhibitors: Structure-activity relationships. J Med Chem 1999;42:4538-46.

14. Read M, Harrison RJ, Romagnoli B, Tanious FA, Gowan SH, Reszka AP, et al. Structure-based design of selective and potent G-quadruplex-mediated telomerase inhibitors. Proc Natl Acad Sci U S A 2001;98(9):4844-9.

15. Heald RA, Modi C, Cookson JC, Hutchinson I, Laughton CA, Gowan SM, et al. Antitumor polycyclic acridines. 8.1 synthesis and telomerase-inhibitory activity of methylated pentacyclic acridinium salts. J Med Chem 2002;45:590-7.

16. Heald RA, Stevens MF. Antitumour polycyclic acridines. Palladium(0) mediated syntheses of quino[4,3,2-kl]acridines bearing peripheral substituents as potential telomere maintenance inhibitors. Org Biomol Chem 2003;1:3377-89.

17. Cheng MK, Modi C, Cookson JC, Hutchinson I, Heald RA, McCarrollAJ, et al. Antitumor polycyclic acridines 20. Search for DNA G-quadruplex binding selectivity in a series of 8,13-dimethylquino[4,3,2-kl]acridinium salts: Telomere-targeted agents. J Med Chem 2008;51(4):963-75.

18. Harrison RJ, Cuesta J, Chessari G, Read MA, Basra SK, Reszka AP, et al. Trisubstituted acridine derivatives as potent and selective telomerase 
inhibitors. J Med Chem 2003;46:4463-76.

19. Fedoroff OY, Salazar M, Han H, Chemeris VV, Kerwin SM, Hurley LH. NMR-based model of a telomerase-inhibiting compound bound to G-quadruplex DNA. Biochemistry 1998;37:12367-74.

20. Kerwin SM, Chen G, Kern JT, Thomas PW. Perylene diimide G-quadruplex DNA binding selectivity is mediated by ligand aggregation. Bioorg Med Chem Lett 2002;12:447-50.

21. Rossetti L, Franceschin M, Schirripa S, Bianco A, Ortaggi G, Savino M. Selective interactions of perylene derivatives having different side chains with inter - And intramolecular G-quadruplex DNA structures. A correlation with telomerase inhibition. Bioorg Med Chem Lett 2005;15:413-20.

22. Franceschin M, Pascucci E, Alvino A, D'Ambrosio D, Bianco A, Ortaggi $\mathrm{G}$, et al. New highly hydrosoluble and not self-aggregated perylene derivatives with three and four polar side-chains as G-quadruplex telomere targeting agents and telomerase inhibitors. Bioorg Med Chem Lett 2007;17:2515-22.

23. Franceschin M, Lombardo CM, Pascucci E, D'Ambrosio D, Micheli E, Bianco A, et al. The number and distances of positive charges of polyamine side chains in a series of perylene diimides significantly influence their ability to induce G-quadruplex structures and inhibit human telomerase. Bioorg Med Chem 2008;16:2292-304.

24. Wheelhouse RT, Sun D, Han H, Han FX, Hurley LH. Cationic porphyrins as telomerase inhibitors: The interaction of tetra-(N-methyl-4pyridyl) porphine with quadruplex DNA. J Am Chem Soc 1998;120:3261-2.

25. Shi DF, Wheelhouse RT, Sun D, Hurley LH. Quadruplex-interactive agents as telomerase inhibitors: Synthesis of porphyrins and structureactivity relationship for the inhibition of telomerase. J Med Chem 2001;44:4509-23.

26. Sasaki S, Ehara T, Sakata I, Fujino Y, Harada N, Kimura J, et al. Development of novel telomerase inhibitors based on a bisindole unit. Bioorg Med Chem Lett 2001;11(4):583-5.
27. Ma Y, Ou TM, Tan JH, Hou JQ, Huang SL, Gu LQ, et al. Synthesis and evaluation of 9-O-substituted berberine derivatives containing azaaromatic terminal group as highly selective telomeric G-quadruplex stabilizing ligands. Bioorg Med Chem Lett 2009;19:3414-7.

28. Franceschin M, Rossetti L, D’Ambrosio A, Schirripa S, Bianco A, Ortaggi G, et al. Natural and synthetic G-quadruplex interactive berberine derivatives. Bioorg Med Chem Lett 2006;16(6):1707-11.

29. Shin-Ya K, Wierzba K, Matsuo KI, Ohtani T, Yamada Y, Furihata K, et al. Telomestatin, a novel telomerase inhibitor from Streptomyces annulus. J Am Chem Soc 2001;123:1262-3.

30. Kim MY, Vankayalapati H, Shin-Ya K, Wierzba K, Hurley LH. Telomestatin, a potent telomerase inhibitor that interacts quite specifically with the human telomeric intramolecular G-quadruplex. J Am Chem Soc 2002;124(10):2098-9.

31. Barbieri CM, Srinivasan AR, Rzuczek SG, Rice JE, Lavoie EJ, Pilch DS. Defining the mode, energetics and specificity with which a macrocyclic hexaoxazole binds to human telomeric G-quadruplex DNA. Nucleic Acids Res 2007;35:3272-86.

32. Tera M, Sohtome Y, Ishizuka H, Doi T, Takagi M, Shin-Ya K, et al. Design and synthesis of telomestatin derivatives and their inhibitory activity of telomerase. Heterocycles 2006;69:505-14.

33. Riou JF, Guittat L, Mailliet P, Laoui A, Renou E, Petitgenet $\mathrm{O}$, et al. Cell senescence and telomere shortening induced by a new series of specific G-quadruplex DNA ligands. Proc Natl Acad Sci U S A 2002;99(5):2672-7.

34. Balijepalli1 MK, Buru AS, Sakirolla R, Pichika MR. Cinnamomum genus: A review on its biological activities. Int J Pharm Pharm Sci 2017;9(2):1-11.

35. Nerdy, Putra ED, Haro G, Harahap U, Hutagaol R, Karsono. In silico screening of hesperetin and naringenin ester derivatives as anticancer against p-glycoprotein. Int J Pharm Pharm Sci 2015;7(2):485-8. 